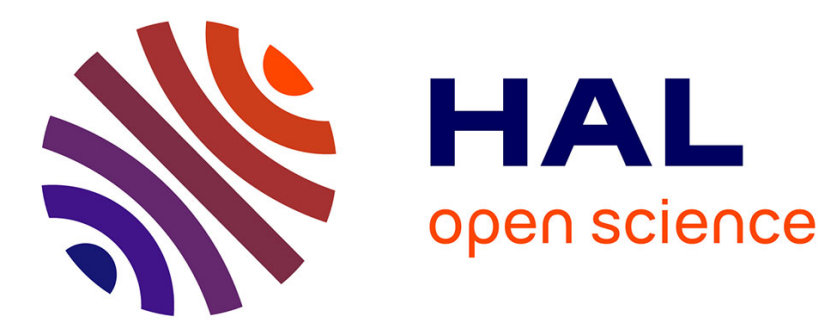

\title{
Verbs and particles in minimal answers to yes-no questions in Czech
}

\author{
Hana Gruet-Skrabalova
}

\section{To cite this version:}

Hana Gruet-Skrabalova. Verbs and particles in minimal answers to yes-no questions in Czech. Formal Description of Slavic Languages 10, Dec 2013, Leipzig, Germany. pp.197-215. hal-00911083

\section{HAL Id: hal-00911083 \\ https://hal.uca.fr/hal-00911083}

Submitted on 24 Feb 2016

HAL is a multi-disciplinary open access archive for the deposit and dissemination of scientific research documents, whether they are published or not. The documents may come from teaching and research institutions in France or abroad, or from public or private research centers.
L'archive ouverte pluridisciplinaire HAL, est destinée au dépôt et à la diffusion de documents scientifiques de niveau recherche, publiés ou non, émanant des établissements d'enseignement et de recherche français ou étrangers, des laboratoires publics ou privés. 


\section{Verbs and particles in minimal answers to yes-no questions in Czech \\ Hana Gruet-Skrabalova \\ Clermont Université, LRL EA 999}

\section{Introduction}

Czech belongs to those languages ${ }^{1}$, in which a yes-no question can be minimally answered not only by answering particles ano ('yes') and ne ('no'), but also by echoing the verb of the question, eventually by combining these two elements, see (1). ${ }^{2}$ When the answer is negative, the verb bears the negative prefix ne-.
Jsou rodiče doma?
are.3pl parents home
- Ano. / Jsou.
// Ne. / Nejsou.
'Are the parents at home?'
yes are.3pl no neg.are.3pl
'Yes (they are).' 'No (they are not).'

The verb in the answer must be finite and bear the same tense feature as the verb in the question, see (2). In case of complex verbal forms with the auxiliary verb být ('be'), past and conditional clitic auxiliaries cannot constitute felicitous answers. This follows if we assume that clitic auxiliaries only bear agreement features and the lexical participle the interpretable tense feature, as proposed by Veselovská (1995). Consequently, the participle may combine with negation and constitute a felicitous answer to polar questions in (3). The future forms of the auxiliary verb být are expected to appear in minimal answers for they bear both tense and agreement features and combine with negation, see (4) ${ }^{3}$.

(2) Pozveš Marii na tu oslavu? - (Ne)pozvu. / *(Ne)pozval. invite.2sg Mary.acc to that party (neg)invite.1sg (neg)invited.sg.m 'Will you invite Mary to the party?' 'I will (not).'

(3) Koupil jsi / bys mu to? - *(Ne)jsem. / *(Ne)bych / (Ne)koupil. bought.sg.m aux/cond.2sg him it (neg)aux.1sg/(neg)cond.1sg/(neg)bought 'Did / Would you buy it for him?' 'I did (not). / 'I would (not).'

(4) Budou pracovat i v neděli? - (Ne)budou. fut.3pl work also on Sunday (neg)fut.1pl 'Will they work on Sunday too?' 'They will (not).'

1 E.g. Basque (Laka 1990), Irish (McCloskey 1991), Portuguese (Martins 1994), Welsh (Jones 1999), Finnish (Holmberg 2001).

2 I do not deal here with answers like možná ('maybe'), samozřejmě ('of course'), and so on.

3 The same contrast between the future auxiliary forms and the past/conditional clitic auxiliaries can be observed in VP-ellipsis constructions (Gruet-Skrabalova 2012b). 
The data presented above raise two issues that will be addressed here: (i) what is the syntactic structure of minimal verbal answers? (ii) what is the syntactic and semantic status of answering particles?

The paper is organized as follows. In section 2, I argue, following Laka (1990), that minimal verbal answers involve clausal ellipsis after movement of the finite verb bearing the focused polarity feature to the CP domain. In section 3, I show the distribution of particles in answers to positive and negative questions. In section 4, I argue that negative questions contain expletive or true negation. In the former case, they behave as positive questions. In the latter case, they behave as negative declaratives that convey a negative presupposition and can be (dis)confirmed by the particles. In section 5, I propose that particles are generated in the specifier of the polarity projection where they express absolute or relative polarity, depending on the polarity of the question. The focused verb moves to the Focus projection below the PolP. The complement of the head of PolP or FocP can be elided for they are given in the question. Section 6 sums up the proposed analysis.

\section{The syntax of verbal answers}

In this section, I argue that minimal verbal answers involve ellipsis of the whole clause except for the finite verb that has been moved to the CP domain for it bears the polarity feature that is focused in yes-no question/answer pairs.

\subsection{Absence of arguments}

Although Czech is a pro-drop language, it is not plausible that minimal verbal answers are full sentences with null pronominal arguments. On the one hand, overt complements are disallowed with the echoing participle, but must be overt in declarative sentences, compare (5a) and (5b). The same holds of reflexive pronouns that are excluded from answers, although they are obligatory in questions and independent clauses, compare (6a) and (6b).
(5a) Poslali jste Pavlovi ten dopis? -Poslali. / *Poslali mu ho. ${ }^{4}$ sent.2pl.m aux.2pl Paul.dat this letter.acc sent.pl.m sent.pl.m him it 'Did you send the letter to Paul?' 'Yes (we did).'

(5b) Rodiče napsali Pavlovi dopis a my jsme *(mu ho) poslali. parents wrote.pl.m Paul.dat letter.acc and we aux.1pl him it sent.pl.m 'The parents wrote a letter for Paul, and we (then) sent it to him.'

4 Poslali mu ho would be a correct answer if the subject were 3p.pl: 'they sent it to him'. 
(6a) Cítíte se jako velký favorit? - Ano, cítím *(se)! (ČNK) ${ }^{5}$

feel.2pl refl as big favourite yes feel.1sg refl

'Did you feel like a real favourite?' 'Yes, I do'.

(6b) Po dobrém tréninku *(se) vždy cítí jako velký favorit. after good training refl always feel.3sg as big favourite 'After a good training, he always feels as a big favourite.'

On the other hand, the presence of an overt subject requires a complete verbal form as well as the obligatory complements, and it is thus disallowed with an echoing participle, see $(7)^{6}$.

(7) Udělal bys to pro pro něj? - Udělal. /*Udělal já. / *Já udělal. done.sg.m cond.2sg it for him done.sg.m done.sg.m I I done.sg.m 'Would you do it for him?' 'Yes (I would).'

- Já bych to udělal, ale nesmím. I cond.1sg it done.sg.m but neg.may.1sg 'I would do it, but I can't.'

The data above imply that minimal verbal answers do not contain any null argument (neither complement nor subject), but rather elided structure involving these arguments. Assuming that 2P-clitics occupy the lowest position in the CP (as proposed by Veselovská 1995), the elided structure would correspond to the whole clause including the clitics (i.e. FinP, see Lenertová 2001, Rizzi 1997).

\subsection{Verbal forms}

An additional piece of evidence for clausal ellipsis comes from the verbal forms themselves. Although participles in replies to questions in past tense and in conditional mood look identical, they are interpreted correctly with respect to tense and mood, as shown in (8). This means that these answers have a complete structure at LF, which follows if they involve an elided clausal structure.

(8a) Poslala jsi mu to? - Poslala (ale teprve včera / \#ale až budu mít čas). sent.sg.f aux.2sg him it sent.sgf but only yesterday but when I have time 'Did you sent it to him?' 'Yes, but I did it only yesterday.'

(8b) Poslala bys mu to? - Poslala (\#ale teprve včera / ale až budu mít čas). sent.sg.f cond.2sg him it sent.sgf but only yesterday but when I have time 'Would you send it to him?' 'I would, when I have time.'

Note also that the verb in the answer does not simply repeat the verb of the question, but it has the form it would have in a full sentence answer, as shown in

5 Annotation $\breve{C} N K$ indicates attested examples from Czech National Corpus.

6 Overt subjects are focused and appear clause-initially. 
(9a), where the second person past auxiliary is reduced to a suffix on the participle only in the question, and in (9b), where the two verbs bear distinct agreement features.

$$
\begin{aligned}
& \text { a. Poslalas mu to? } \quad-\text { Poslala. }=(8 \mathrm{a}) \\
& \text { b. Pošleš mu to? - Pošlu. } \\
& \text { send.2sg him it send.1sg } \\
& \text { 'Will you send it to him?' 'Yes (I will).' }
\end{aligned}
$$

Clausal ellipsis would furthermore explain why answers containing complex verbal forms without arguments are not felicitous, as in (10a). This observation does not hold for modal verbs in (10b), which may appear with or without auxiliary clitics. Modal verbs differ however from lexical verbs in that they allow VP-ellipsis (see Gruet-Skrabalova 2012b), as shown in (11). Consequently, I claim that answers containing modal verbs may correspond to two different constructions illustrated in (12): clausal (FinP) ellipsis in absence of clitics, and VPellipsis in presence of clitics.

(10a) Zúčastnil byste se té soutěže -Zúčastnil (*bych). participated.sg.m cond.2pl refl this competition.gen participated.sg.m cond.1sg 'Would you take part in this competition?'

(10b) Chtěl byste se zúčastnit té soutěže? - Chtěl (bych). wanted.sg.m cond.2pl refl participate this competition.gen wanted.sg.m cond.1sg 'Would you like taking part in this competition?'

(11) Plánoval jsem jet $\mathrm{k}$ moři, ale manželka nechtěla [vp jet k moři]. planned.sg.m aux.1sg go to sea but wife neg.wanted.sg.f go to sea 'I planned to go to the sea, but my wife did not want to.'

(12) Chtěl [FinP Ø]. / Chtěl bych pro $\mathrm{t}_{\mathrm{v}}[\mathrm{vP} \varnothing]$. wanted.sg.m wanted.sg.m cond.1sg

Finally, minimal verbal answers may be modified by sentential (modal) adverbs that are presumably generated in the CP domain (Cinque 1998), which also suggests that they have an underlying $\mathrm{CP}$ structure.

(13) Mluví Jan italsky? - Asi mluví. / Nejspíš nemluví. speaks.3sg Jan Italian 'Does Jan speak Italian?' probably speak.3sg most-probably neg.speak.3sg 


\subsection{Ellipsis analysis}

To account for verbal answers, I first assume, following Laka (1990), that clauses contain a functional projection in the $\mathrm{CP}$ domain that encodes polarity ${ }^{7}$. I also assume that the polarity of yes-no questions is open in the sense that polar questions ask [P or not P], cf. Hamblin (1973). The cases where this assumption does not hold are discussed in section 3. Laka (1990) argues that in answers to yes-no questions in Basque, the head of the polarity projection is obligatorily realized by an overt polarity particle $(b a, e z)$, to which the finite verb must right-adjoin because it is focused. The IP is then deleted, see (14).

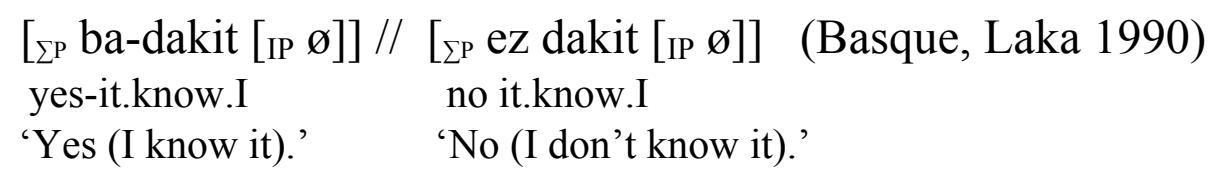

We have seen that verbal answers in Czech only contain the finite verb. It seems therefore plausible that the verb moves out of the IP to the CP domain, because it bears the interpretable polarity feature that is focused in yes-no questionanswer pairs (see Holmberg 2001, Gruet-Skrabalova 2012a). In other words, the finite verb assigns a positive or negative polarity value to the head encoding polarity. The complement of this head, i.e. clause including second position clitics (FinP), would then be elided, for it is given in the question, as shown in (15).

I assume that morphological difference between the verb in the answer and its antecedent in the question, due to agreement features, is not relevant for ellipsis. Other elliptical constructions, e.g. gapping in $(16 a)^{8}$ or short answers to wh-questions in (16b), show that identity between deleted materiel and its antecedent is not based on their surface structure (see Goldberg 2005, Merchant 2001, 2013 ${ }^{9}$ ).

$$
\begin{array}{cc}
\text { [PolP Pošleš [FinP mu } t \text { ten dopis }]] ? & -\left[\text { PolP Pošlu }_{[+]}[\text {FinP } t \text { ten dopis }]\right] \\
& -[\text { PolP Nepošlu } \\
\text { (will you) send.2sg him the letter } & \text { (neg)send. } 1 \mathrm{sg} \text { him } \text { hum this letter }
\end{array}
$$

(16a) Já mluvím francouzsky a Jan (mluví) italsky.

I speak.1sg French and Jan (speak.3sg) Italian

7 "Both Neg(ation)P and Aff(irmation)P are claimed to be different instantiations of a more abstract projection: the $\sum$ Phrase." (Laka 1990: 86)

8 This allows to have a unified analysis of gapping in languages without and with a rich verbal morphology, like English and Czech:

I eat apples and the other children (eat) pears. / Já jím jablka a ostatní děti (jedí) hrušky.

9 "Any identity relation based on morphological or phonological identity (of the elided verb phrase) with its antecedent would be clearly wrong." (Merchant 2013:27) 
(16b) Co jsi poslala Petrovi? - Dopis (jsem mu poslala). what aux.2sg sent to-Peter letter (aux.1sg him sent)

The analysis proposed here will be revised in section 5 to account for the role of the particles as well as for their combining with (not only) verbal answers.

\section{Answering particles}

In this section, I discuss the distribution of answering particles in answers to positive and negative questions. I show in particular that there are two types of answers to negative questions, which are not equivalent: polarity-based answers and truth-based answers.

\subsection{Particles in answers to positive questions}

If we use particles to answer positive questions, i.e. questions containing a positive verb, they will function in the same way as the verbal answers do. So, ano will express a positive answer and combine with a positive verb, while ne will express a negative answer and combine with a negative verb, as shown in (17). Pope (1972) calls such answers polarity-based answers, for particles seem to indicate the polarity value of the answer.
(17) Jsou rodiče doma?
- Ano (jsou). // $\mathrm{Ne}$ (nejsou).
are.3pl parents home
yes are.3pl no neg.are.3pl
'Yes (they are).' ' 'No (they are not).'

Given that particles and verbs in (17) express the same value, I propose following Holmberg (2001) that particles are generated in the specifier of the polarity projection where they agree with the verb in the polarity head according to Spechead agreement (Chomsky 1991), as shown in (18). Assuming further that the verb can move at LF, we explain that the particles appear alone. When the verb moves overtly, particles have an emphatic role and are thus facultative. ${ }^{10}$

$$
\begin{aligned}
& \text { [PolP Pošleš [FinP mu } \left.t \text { ten dopis]] - [PolP Ano }{ }_{[+]}\left[\mathrm{Pol} \text { pošlu } \mathrm{u}_{[+]}[\mathrm{FinP} \varnothing]\right]\right] \\
& -\left[\text { PolP } \mathrm{Ne}_{[-]}\left[\text {Pol' nepošlu }{ }_{[-]}[\mathrm{FinP} \varnothing]\right]\right]
\end{aligned}
$$

10 Verbal answers in Basque can also be preceded by the particle bai ('yes') or ez ('no'). Laka claims that these particles are not in $\Sigma \mathrm{P}$, but their syntactic status is not clear. 
The proposal in (18) correctly predicts that both particles and verbs can be embedded under a complementizer $(C)^{11,12}$, as shown in (19), and modified by a CP adverb, as shown above (see ex. (13), section 2.2):

$$
\begin{aligned}
\text { Mluví Jan francouzsky? } & \text { Myslím, [CP Že [FocP ano / ne [FinP Ø]]]. } \\
\text { speak.3sg John French } & \text { think.1sg that yes no } \\
- & \text { Myslím, [CP Že [FocP (ne)mluví [FinP Ø]]]. } \\
& \text { think.1sg that (neg)speak.3sg }
\end{aligned}
$$

But the analysis also predicts that particles and verbs always agree, which is not true in all answers to negative questions, as we will see in section 3.2. Moreover, although the particles are used in the same way independently of whether the question is interpreted as an informative question or not, e.g. a dubitative question in (20a), the proposal does not account for answers to formally polar questions that only ask to confirm a focused XP, as in (20b). I will come back to these answers in section 5.

(20a) On si koupil Škodovku?! (tomu nemůžu věřit) - Ano, koupil.

$-\mathrm{Ne}$, nekoupil.

he refl bought Skoda this neg.can.1sg believe yes bought / no neg.bought 'Did he buy a Skoda? (I can't belive that!)' 'Yes, he did.' / 'No he did not.'

(20b) Petr si koupil ŠKODOVKU? (a ne jiné auto) - Ano, ŠKODOVKU. - Ne, S̆KODOVKU, ne.

Peter refl bought Skoda and not another car yes Skoda / no Skoda not

'Did Peter buy a Skoda? (not another car)' 'Yes / No, he bought / did not buy S.'

\subsection{Particles in answers to negative questions}

Verbal answers to negative questions are identical to verbal answers to positive questions. But if we look more carefully on particles, we observe that both ano and $n e$ can be used to confirm a negative question as in (21ab) or to deny it as in ( $21 \mathrm{~cd})$, where ano is furthermore obligatorily preceded by the conjunction ale ('but') ${ }^{13}$. Consequently, particles and verbs do not always agree, since ano cooccurs with a negative verb in (21b) and ne with a positive verb in (21d).

(21a) Nestal se Jan Pavel I. obětí zločinných intrik? - Ne, nestal. (ČNK) neg.become refl John Paul I victim (of) criminal plots no neg.become 'Did Pope John Paul not become a victim of a criminal plot?' 'No, he did not.'

11 The complementizer $\check{z} e$ ('that') is always overt in Czech.

12 Their co-occurrence is possible, but pragmatically odd, because the matrix predicate (a mental verb or a predicate of saying) expresses itself emphasis or rather doubt.

13 See section 5.2 for further remarks on ale ano/ale ne. 
(21b) Irán tedy svou politiku prakticky nezměnil? - Ano, nezměnil. (ČNK) Iran thus his politics really neg.changed 'Did Iran really not change his politics?'

yes neg.changed

'No, he did not change.' (21c) Vy nemluvíte anglicky? you neg.speak.2pl English 'Do you not speak English?'
- Ale ano, mluvím. (ČNK)

but yes speak.1sg

'No, I do speak English.'

(21d) Oni ten návrh nepřijali? - Ne, přijali. (ČNK)

they that proposal neg.accepted no accepted

'Did they not accept the proposal?' 'No, they did accept it.'

However, the 'double' use of ano and ne in (21) does not mean that both particles are equally available in all answers to negative questions, as shown in table 1. So, ne can always accompany a negative verb, and ano/ale ano a positive verb, while the opposite is not true.

Table 1: $\quad$ Yes and no in answers to negative questions

\begin{tabular}{|c|c|c|c|c|c|}
\hline & \multicolumn{2}{|c|}{ Negative answer } & \multicolumn{3}{|c|}{ Positive answer } \\
\hline & ne + neg-V & ano + neg-V & ano $+V$ & ale ano $+V$ & ne $+V^{14}$ \\
\hline (21a) & ne, nestal & *ano, nestal & ano, stal & ?ale ano, stal & $*^{*}$ ne, stal \\
\hline (21b) & ne, nezměnil & ano, nezměnil & *ano, změnil & ale ano, změnil & ne, změnil \\
\hline (21c) & ne, nemluvím & ?ano, nemluvím & *ano, mluvím & ale ano, mluvím & ?ne, mluvím \\
\hline (21d) & ne, nepřijali & ano, nepřijali & *ano, přijali & ale ano, přijali & ne, přijali \\
\hline
\end{tabular}

Holmberg (2013) argues that in English, negative questions answered by yes are positive questions containing VP-negation, because only sentences with low not, which are ambiguous between sentential and VP negation reading, can be answered by yes, see (22). Answers no+positive $V$ are only mentioned in a footnote, because they are very difficult to obtain in English. This is however surprising, since positive questions should be easily denied by no.

(22a) Is John not coming? - No. (sentential negation) / Yes. (VP-negation) (22b) Isn't John coming? - No. (sentential negation)/*Yes. (*VP-negation)

If we assume following Kosta (2001) that negative verbs in Czech are always ambiguous between sentential and VP-negation reading, this distinction cannot explain why ano+negative $V$ and ne+positive $V$ may answer only a subset of negative questions. Consequently, I'd rather argue in the following section that use of particles depends on whether sentential negation is interpreted as true or as expletive. Only questions containing true negation, thus conveying a negative presupposition, will be confirmed by ano and denied be ne. Such answers are called by Pope (1972) truth-based answers.

14 Ne can be accompanied by ale, see section 4.2 . 


\section{Negative questions}

In this section, I argue that we have to distinguish between negative questions with expletive negation and negative questions with true negation (see e.g. Brown \& Franks 1995 and Abels 2002). The former ones behave as positive questions, while the latter ones behave as negative assertions, that can be confirmed by ano and denied by ne. Questions with true negation are syntactically rising negative declaratives (see Gunlogson 2001).

\subsection{Negative questions with expletive vs. true negation}

It has been claimed for Russian (Brown \& Franks 1995) that there are several semantic types of negative questions ${ }^{15}$ and that only presumptive and emotionally charged questions have a negative presupposition, i.e. they contain true sentential negation. The other ones contain expletive negation, i.e. a formally negative morpheme, but semantically void of content (cf. pleonastic negation in Romance languages, Espinal 1992). Abels (2002) argues that negative morpheme is always semantically negative since it licenses Genitive of Negation, but it becomes expletive when it is attracted by an interrogative complementizer. Consequently, it is not able to license $n i$-phrases in Russian. ${ }^{16}$ The analysis implies that expletive negative morpheme occurs high in the syntactic structure.

Although Czech main questions do not usually contain any interrogative complementizer, questions with initial negative verb as in (23a) do not license $n i$-phrase as subject, like positive declaratives in (23d), while questions with non initial verb as in (23b) licences it, like negative declaratives in (23c). This suggests that (23a) contains expletive negation while (23b) contains true negation.

(23a) Neví *nikdo / někdo, jak se to dělá?

neg.know.3sg nobody/somebody how refl this make.3sg

'Does anyone know how this is done?'

(23b) Nikdo / Někdo neví, jak se to dělá?

nobody / somebody neg.know.3sg how refl this make.3sg

'Nobody knows how this is done?'/ 'Somebody doesn't know how this is done?'

(23c) Nikdo / Někdo neví, Jak se to dělá.

nobody / somebody neg.know.3sg how refl this make.3sg

'Nobody knows how this is done.'/ 'Somebody doesn't know how this is done.'

15 I.e. informative, rhetoric, dubitative, presumptive and emotionally charged questions.

16 The contrast is not relevant for Czech, because Czech does not have Genitive of Negation. 
(23d) Někdo / *Nikdo ví, jak se to dělá. somebody / nobody know.3sg how refl this make.3sg 'Somebody knows how this is done.'

Answers in (24ab) confirm our hypothesis. Question (23a) can only be answered by $n e$ (nevi) and ano (vi), exactly as a positive question. Question (23b) with nikdo can be confirmed both by ne and by ano and denied by ale ano and ne. The negative morpheme ne-can (but not must) be therefore interpreted as true negation, if the verb does not move overtly to the CP domain. Question (23b) with někdo can only be confirmed by ano and denied by ne, see (24c). It therefore behaves as negative assertions (see section 4.2).

(24a) Neví někdo, jak se to dělá? - Ne, neví. / *Ano, neví. // Ano, ví.

(24b) Nikdo neví, jak se to dělá? - Ne / Ano (nikdo to neví).

- Ale ano / NE (někdo to ví).

(24c) Někdo neví, jak se to dělá? - Ano (někdo to neví). // Ne (všichni to vědí). yes somebody it neg.knows / no everybody it knows

Furthermore, both particles in (24b) may combine with the negative word, as in positive questions with a focused XP (see (19) above), see (25a) and (25b), where the negative word appears in object DP . The denial would be expressed by (ale) ne or ale ano accompanied by a positive clause: někdo to ví ('someone knows it'), nějakou pozval ('he invited some schoolmate').

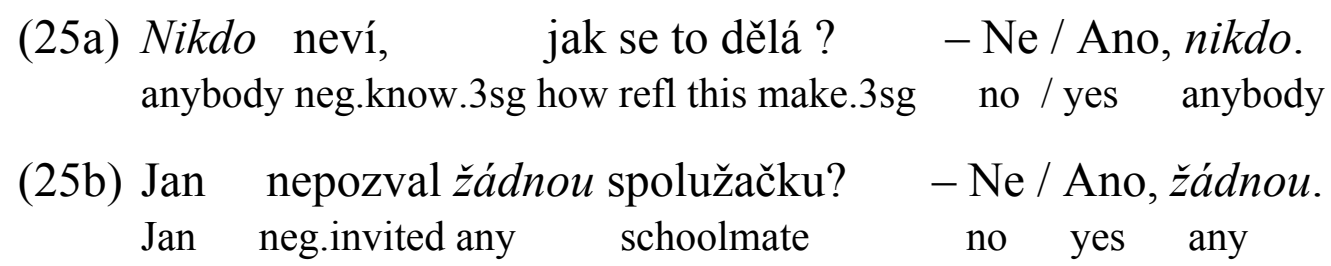

Finally, when the question contains an interrogative particle like copak in (26a), it can be answered exactly like a positive question, which again shows that negation here is interpreted as expletive. However, when the verb appears below the subject in (26b), it is still able to license the subject nikdo. Negation in (26) seems therefore expletive only with respect to the polarity of the question and not with respect to $n i$-phrases. This confirms Abel's (2002) proposal that negation becomes expletive by virtue of its movement to the $\mathrm{C}$.

(26a) Copak zdravotní systém v Americe není drahý? - Ano, je. (ČNK) INT.PART health system in America neg.is expensive yes is 'Isn't the American health system expensive?' 'Yes, it is.'

(26b) Copak nikdo neví, jak se to dělá ? - Ne / Ano, nikdo. INT.PART anybody neg.know.3sg how refl this make.3sg 'Does nobody know how this is done?' 'No, nobody.' 
I conclude that negation in questions with clause-initial negative verb (i.e. before the subject) is interpreted as expletive and that such questions behave as positive questions, as shown in (27). In contrast, negation in questions with noninitial negative verb can be interpreted as true negation. Consequently, such questions are confirmed by ano $(+n e-V)$ and denied by $n e(+V)$. In next section, I argue that these questions are negative rising declaratives.

(27a) Nechtěl byste šálek čaje? - Ano (*ne)chtěl. // Ne*(ne)chtěl. neg.wanted cond.2pl cup tea yes wanted no neg.wanted 'Would you like a cup of tea?' 'Yes (I would).' / 'No (I would not).'

(27b) Nestal se Jan Pavel I. obětí intrik? - Ano, (*ne)stal. // Ne, *(ne)stal. neg.become refl JPI victim (of) plots yes become no neg.become 'Didn't Pope John Paul I become a victim of a plot?' 'Yes, he did.' / 'No, he did not.'

\subsection{Negative rising declaratives}

Questions can be expressed not only by interrogative sentences, but also by declarative sentences with rising intonation (so-called rising declaratives). Gunlogson (2001) argues that such rising declaratives are non neutral questions that differ from interrogative sentences in that they convey a presupposition, like declaratives sentences. ${ }^{17}$ Following Gunlogson, I claim that negative questions confirmed by ano and denied by ne are rising declarative that convey a negative proposition and are used to elicit the agreement or disagreement of the addressee with this negative proposition.

Evidence for this claim comes both from the form and from the meaning of these questions. First, they contain a non initial negative verb, like declarative sentences (cf. section 4.1). Second, they are always interpreted as non neutral questions, conveying a negative presupposition. ${ }^{18}$ So, if A. says to me that she doesn't see well at a certain distance and I ask her (28), I presuppose that she can't read the panels. If she replies ano (familiarly jo), she confirms this negative presupposition. But if she can still read the panels, she would say (ale) ne / ale ano. The question in (28) therefore behaves as the negative declarative assertion in (29) that expresses a negative proposition and is also confirmed by ano and denied by $n e$.

17 Gunlogson (2001:22-25): Rising declaratives are unsuitable in contexts where the speaker is expected to maintain an attitude of neutrality or ignorance. Consequently, they cannot be used to raise an open issue, to solicit an opinion, nor to instigate a discussion.

18 I rely on attested examples from the CNK and on judgements of 34 native speakers, who kindly answered my questionnaire. I also rely on my own intuition. The example (28) is taken from a true conversation. 
Ty na ty cedule nevidíšs you on the panels neg.see.2sg 'You cannot read the panels?'
- Jo (nevidím). // - (Ale) ne / Ale jo (vidím). yes neg.see.1sg (but) no but yes see.1sg 'No, I cannot. // 'Yes, I can.'

(29) Anna na ty cedule nevidí. Anna the panels neg.see.3sg - Jo, to se dalo čekat, její rodiče nosí brýle. yes this refl could expect her parents wear glasses 'A. cannot read the panels.' 'Yes, that's what we could expect, for her parents wear glasses.' - Ne, to není možný, vždyt' vždycky dobře viděla! 'No, that's impossible, she has always had a good sight!'

Furthermore, negative declaratives used as questions behave like declaratives with respect to negative polarity items in that they license the subject nikdo (nobody), see (23) above.

Finally, particles in answers to negative declaratives are usually emphasized and separated from the following verbal answer by a pause. The particle ne can also be accompanied by the conjunction ale that emphasizes disagreement with the negative expectations of the question, as in (28b). This indicates that the particle is more related to the presupposition conveyed by the question than to the polarity expressed by the following verb. I conclude that negative questions confirmed by ano and denied by ne are negative declarative sentences used as questions that convey a negative presupposed proposition. Consequently, answering particles are used by the addressee to (dis)agree with this proposition.

\section{Proposal}

In this section, I propose a semantic and syntactic analysis of minimal answers containing particles and verbs. Particles are generated in the specifier of the polarity projection where they express absolute or relative polarity, depending on the polarity of the question. The focus verb or another focused XP move to the Focus projection below the PolP. The complement of the head PolP and FocP can be elided for they are given in the question.

\subsection{Absolute vs. relative polarity}

To account for the distribution of answering particles in answers that have been presented in the previous sections, I propose that particles express either absolute polarity, or relative polarity. Absolute polarity is the feature that has two values: positive [+] and negative [-]. Relative polarity, defined in Farkas (2010) as the relation between the absolute polarity of the question [Q] and the absolute polarity of the answer [A], is a feature that also has two values: same [Q,A] and reverse $[\mathrm{Q}, \mathrm{A}]$. The value same means that the polarity of the question and that of 
the answer are identical. The value reverse means that they are different. Given the absolute polarity of the question and of the answer, the value same can have two interpretations: $[+,+]$ and $[-,-]$. Likewise, the value reverse can have two interpretations: $[+,-]$, and $[-,+]$.

Positive questions and negative questions with expletive negation have open polarity, because they ask [P or not P]. Consequently, the particle ano expresses the positive value $[\mathrm{P}]$ and the particle ne the negative value [not $\mathrm{P}]$. On the contrary, negative rising declaratives have negative polarity and only ask to confirm [not P]. Consequently, the particle ano confirms the same value [not P], while the particle no disconfirms [not $\mathrm{P}$ ], thus implies the reverse value [P]. More precisely, ano realizes the value $[-,-]$, and $n e$ the value $[-,+]$. In some other languages, this value is realized by a specific reversing particle. ${ }^{19}$

The second interpretation of same and reverse applies in answers that convey a positive presupposition (i.e. positive rising declaratives). Here ano realizes the value $[+,+]$ and $n e$ the value $[+,-]$, which implies that these answers are at surface identical to answers where particles express absolute polarity, thus $[+]$ in case of ano and [-] in case of $n e$ (see section 3.1).

\subsection{Particles and verbs}

To account both for particles that agree with the verb and for the particles that (dis)agree with the questions presupposition, I propose to revise the analysis of verbal answers and agreeing particles in section 3.1 in the following way.

First, I propose that particles are always generated in the specifier of the PolP. When the polarity of the head is open, the particles assign the value $[+]$ or $[-]$ to this head, see (30). When the polarity is given (in the presupposed proposition), the particle express the value [same] or [reverse] with respect to this polarity, see (31). In both cases, the complement of PolP can be elided.

$$
\begin{aligned}
& \text { Pošleš } \left.{ }_{[\mathrm{x}]} \text { mu ten dopis? } \quad-\text { PPolP } \mathrm{Ano}_{[+]}\left[\mathrm{Pol}^{[+]}[\mathrm{XP} \emptyset]\right]\right] \\
& \text { (will you) send.2sg him the letter }-\left[\mathrm{PolP} \mathrm{Ne}_{[-]}\left[\mathrm{Pol}^{\prime}{ }_{[-]}[\mathrm{XP} \varnothing]\right]\right]
\end{aligned}
$$

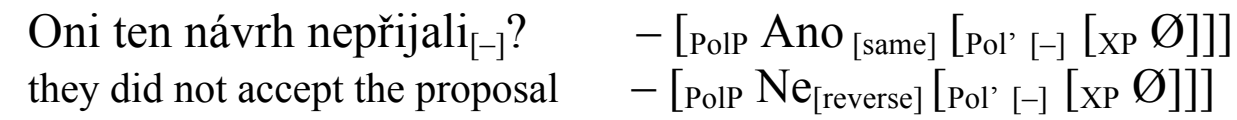

Second, the verb in verbal answers moves to the head of Focus projection below PolP, because it is focused, see (32) and (33). Since the verb bears itself the polarity feature of the answer, the particle are not necessary if the verb moves overtly. Answers combining both elements are emphatic, and verbs and particles 'agree' in (33).

19 E.g. si in French, doch in German or ba in Romanian (see Farkas 2010). 
(32)

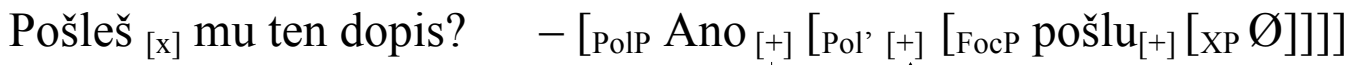

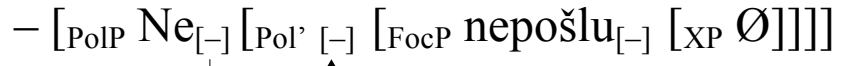

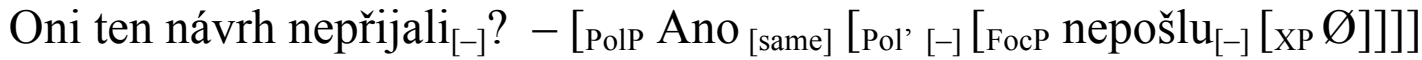

$$
\begin{aligned}
& \text { - [PolP } \left.\left.\mathrm{Ne}_{\text {[reverse] }}\left[\text { Pol’ [-] [FocP pošlu }{ }_{[+]}[\mathrm{XP} \varnothing]\right]\right]\right]
\end{aligned}
$$

In answers containing a focused XP as in (19b) above, this XP moves to the specifier of Focus projection below PolP, see (34). The head of FocP must contain an overt negation (ne or negative verb) in case of negative answer, since the negative value cannot be given by the focused XP (contrary to the focused verb). ${ }^{20}$

(34) Petr si koupil ${ }_{[+]}$Škodovku?

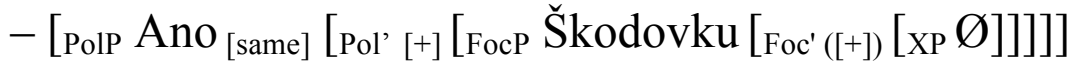

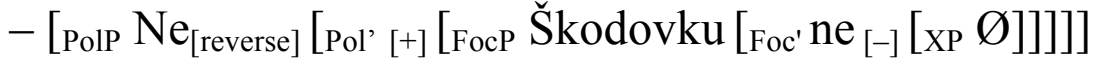

Peter refl bought Skoda yes Skoda // no Skoda not

As for the adversative conjunction ale ('but'), it only appears in reverse contexts, as shown e.g. in (21a) and (28) above. Furthermore, ale is not obligatory with verbs nor with the particle ne, but it is obligatory with ano, see (35). I claim that ale is not obligatory when the change of polarity is indicated by ne or by the polarity of the verb, while it is obligatory with ano, because ano is interpreted as [same] or [+]. By combining with ano, the conjunction ale adds the meaning of opposition to positive answers to negative questions (thus ale ano $V$ ) and distinguishes them from positive answers to positive questions (i.e. ano $V$ ). ${ }^{21}$

$$
\begin{aligned}
& \text { Vy nemluvíte anglicky? } \\
& \text { you neg.speak.2pl English ne, mluvím. / (*Ale) ano, mluvím. } \\
& \text { 'Do you not speak English?' }
\end{aligned}
$$

Finally, the proposal above does not directly predict that embedded particles always express absolute polarity, as shown in (36) (cf. (18) above). However, Gunlogson (2001) argues that rising declaratives commit the addressee to the

20 According to this proposal, ellipsis in verbal answers and answers containing an XP can be considered as instances of sluicing, for it has been argued (Stjepanović 2003, Grebenyova 2006) that sluicing in Slavic languages is triggered by focus feature.

21 Czech is thus in "mid way" between languages like Spanish that use a unique particle yes in all positive answers and languages like French that possess two different particles yes:

Spanish: ¿Viene? (Is he coming?) Sí, viene. (Yes, he is.) ¿No viene? (Is he not coming?) Sí, viene. (Yes, he is.)

French: Il vient? (Is he coming?) Oui, il vient. / * Si, il vient. (Yes, he is.) Il ne vient pas? (Is he not coming?) *Oui, il vient. / Si, il vient. (Yes, he is.) 
propositional content, which implies that the addressee must be able to reply such questions by a straightforward answer. I leave this issue for further research.

$$
\begin{aligned}
& \text { Jan nemluví francouzsky? - Myslím, že ne (= nemluví / f mluví). } \\
& \text { John neg.speak.3sg French think.1sg that no neg.speak.3sg speak.3sg } \\
& \text { - ?Myslím, že ano (= mluví / } \neq \text { nemluví). } \\
& \text { think.1sg that yes speak.3sg neg.speak.3sg }
\end{aligned}
$$

\section{Summary}

In this paper, I examined verbs and answering particles in minimal answers to yes-no questions in Czech.

I argued that minimal answers involve ellipsis of the clause (IP) including second position clitics except for the verb that moves to the CP domain and the particles that are generated in the polarity projection in the CP domain. The verb moves to the FocP because it bears the polarity feature that is focused in polar question-answer pairs. Other focused XPs can also move to FocP.

I also argued that negative questions contain expletive or true negation. In the former case, they behave as positive (open) questions, while in the latter case, they behave as negative declaratives, i.e. convey a negative presupposition and have a fixed polarity. Negative questions containing true negation are confirmed by ano and denied by ne, because the particles here (dis)confirm the polarity of the presupposition conveyed by the question. To account for distribution of the particles, I proposed that particles express two kinds of polarity: (i) absolute polarity $[+]$ or $[-]$ in answers to open questions, and (ii) relative polarity [same] or [reverse] in answers to questions with fixed polarity. Relative polarity simply indicates whether the polarity of the question and that of the answer are identical or different. The proposed analysis does not claim that there are two ano or ne in the lexicon. Rather, each particle is a single lexical item, whose polarity is interpreted in an absolute or in a relative way.

\section{Bibliography}

Abels, K. 2002. Expletive (!) Negation. In J. Toman (ed.), Proceedings of FASL 10, 1-20.

Brown, S. \& S. Franks. 1995. Asymmetries in the scope of Russian negation. Journal of Slavic Linguistics, 3/2, 239-287.

Cinque, G. 1998. Adverbs and Functional Heads. Oxford: Oxford University Press.

Czech National Corpus - SYN2010. Institute of the Czech National Corpus, Praha 2010. Available at: http//www.korpus.cz

Espinal, M.T. 1992. Expletive Negation and Logical Absorbtion. Linguistic Review 9, 333-358.

Farkas, D. 2010. The grammar of polarity particles in Romanian. In A. Di Sciullo \& V. Hill (eds.) Edges, Heads, and Projection: Interface properties, Amsterdam: Benjamins, 81-124. 
Gruet-Skrabalova, H. 2012a. Ellipsis in answers to polar questions in Czech. International conference Topics in the Typology of Elliptical Constructions II, June 27, 2012, University Paris 7 \& Chicago Center Paris.

Gruet-Skrabalova, H. 2012b. VP-ellipsis and the Czech auxiliary být ('to be'). XLinguae 5.4, 3-15.

Goldberg, L.M. 2005. V-stranding VP Ellipsis: A cross-linguistic study. PhD diss. McGill University, Montreal.

Grebenyova, L. 2006. Sluicing and Multiple Wh-fronting. In N. Richa \& S. Sinha (eds), Proceedings of GLOW in Asia, 5, 219-242.

Gunlogson, C. 2001. True to form: Rising and Falling Declaratives as Questions in English. PhD diss. Univ. of California at Santa Cruz.

Hamblin, C. L. 1973. Questions in Montague English. Foundations of Language 10, 41-53.

Holmberg, A. 2001. The syntax of yes and no in Finnish. Studia linguistica 55, 141-174.

Holmberg, A. 2013. The syntax of negative questions and their answers. In N. Gato et al. (eds), Proceedings of GLOW in Asia 9, 1-18.

Jones, B. M. 1999. The Welsh answering system. Berlin: Mouton de Gruyter.

Kosta, P. 2001. Negace a větná struktura češtiny. Čeština - univerzália a specifika 3, 117-138.

Laka, I. 1990. On the Syntax of Negation. PhD. Diss. MIT.

Lenertova, D. 2001. On Clitic Placement, Topicalization and CP-Structure in Czech. In G. Zybatow et al., Current Issues in Formal Slavic Linguistics. Frankfurt/Main: P. Lang, 294-305.

Martins, A. 1994. Enclisis, VP-deletion, and the nature of Sigma. PROBUS, 6.2-3, 173-206.

McCloskey J. 1991. Clause structure, ellipsis, and proper government in Irish. Lingua 85, 259-302.

Merchant, J. 2001. The syntax of silence. Oxford: Oxford University Press.

Merchant, J. 2013. Ellipsis: A Survey of analytical approaches. Ms. University of Chicago.

Pope, E. 1972. Questions and answers in English. PhD. Diss. MIT.

Rizzi, L. 1997. The Fine Structure of the Left Periphery. In L. Haegeman (ed.), Elements of Grammar. A Handbook in Generative Syntax. Kluwer, Dordrecht, 281-337.

Stjepanović, S. 2003. Multiple Wh-Fronting in Serbo-Croatian Matrix Qustions and the Matrix Sluicing Constructions. In C. Boeckx \& K. Grohmann (eds), Multiple Wh-fronting, Amsterdam, J. Benjamins.

Veselovska, L. 1995. Phrasal Movement and $X^{\circ}$ Morphology: Word order parallels in Czech and English nominal and verbal projections, Ph.D. diss. Univerzita Palackého. 